\title{
PENGARUH BAURAN PEMASARAN TERHADAP KEPUTUSAN PEMBELIAN (STUDI PADA INA COOKIES BANDUNG)
}

\author{
Fiera Aryati Natakusumah', Ai Lili Yuliati2 \\ 1,2)Prodi S1 Administrasi Bisnis, Fakultas Komunikasi dan Bisnis, Universitas Telkom \\ E-mail: 1fiera.aryati@gmail.com, 2Ailili1955@gmail.com
}

\begin{abstract}
This research is motivated by the problems related to the marketing mix Ina Cookies. Those problems based on the results of the initial interview is indicative of consumer complaints related to marketing mix consisting of product, price, place and promotion. This study aims to determine the effect of marketing mix consisting of product, price, place and promotion on purchase decisions. The method used is quantitative method with descriptive research and causal. Source data using primary and secondary data, sampling techniques using Non Probability sampling with incidental sampling with the number of respondents as many as 400 people. Data were analyzed using descriptive analysis and multiple linear regression analysis.The results showed that the mix of marketing and consumer purchase decisions on Ina Cookies included in either category. The marketing mix consists of product, price, place and promotion simultaneously or partially positive and significant impact on purchasing decisions.
\end{abstract}

Keywords: Ina Cookies, Marketing Mix, Purchase Decision, Multiple Linear Regression

\section{Pendahuluan}

\section{Latar Belakang Penelitian}

Ekonomi kreatif di Indonesia merupakan sektor yang menjanjikan karena dapat membawa kemajuan dan kesejahteraan bagi masyarakat. Indonesia mempunyai potensi yang menjanjikan dalam industri ini karena Indonesia memiliki keanekaragaman budaya yang dapat menghasilkan kreatifitasnya sendiri. Salah satu sektor ekonomi kreatif yang memiliki peranan penting dalam pertumbuhan ekonomi kreatif adalah sektor kuliner. Sektor kuliner merupakan sektor yang menyumbang pendapatan terbesar dalam industri kreatif. Berbagai data menunjukan bahwa kontribusi wisata kuliner terhadap perekonomian sebesar $25 \%$. (Sumber: www.antaranews.com, diakses 20 Febuari 2015). 


\section{Fiera Aryati Natakusumah}

\section{Ai Lili Yuliati}

Industri kuliner saat ini tidak hanya untuk memenuhi kebutuhan biologis manusia, melainkan untuk memenuhi kebutuhan manusia untuk bersosialisasi maupun aktualisasi. Sebab, industri kuliner yang berkembang saat ini juga memberikan ruang bagi konsumen untuk bisa berkumpul dengan komunitasnya melalui layanan ruangan maupun jasa lainnya. Sehingga setiap tahunnya industri makanan maupun restoran terus mengalami peningkatan seperti yang tertuang pada tabel 1.1 berikut ini:

Tabel 1.1

\section{Perkembangan Usaha Restoran/ Rumah Makan Bersekala Menengah Atau Besar Pada Tahun 2007-2010}

\begin{tabular}{|c|c|c|c|}
\hline \multirow{2}{*}{ Tahun } & \multicolumn{2}{|c|}{ Usaha/Perusahaan } & \multirow{2}{*}{ Rata-Rata Tenaga Kerja } \\
\cline { 2 - 4 } & Jumlah & Pertumbuhan (\%) & \\
\hline 2007 & 1.615 & & 27 \\
\hline 2008 & 2.235 & 38.39 & 27 \\
\hline 2009 & 2.704 & 20.98 & 27 \\
\hline 2010 & 2.916 & 7.84 & 27 \\
\hline
\end{tabular}

Sumber: www.budpar.go.id, diakses 16 Juni 2015

Industri kue kering merupakan salah satu industri kuliner yang ada di Indonesia dan industri ini cukup diminati oleh para pelaku usaha, termasuk di Bandung. Saat ini persaingan industri kue kering di Bandung terbilang cukup ketat karena semakin banyaknya pelaku usaha yang mulai menggeluti usaha di bidang kue kering. Perusahaan kue kering yang cukup sukses di Indonesia salah satunya adalah Ina Cookies. Di era persaingan bisnis yang semakin ketat ini, Ina Cookies dituntut untuk memiliki beberapa keunggulan yang dapat membedakan produk perusahaannya dari perusahaan lain yang dapat dijadikan competitive advantage sehingga perusahaan dapat bersaing dengan perusahaan lain yang sejenis. Dalam competitive advantage konsep yang biasa disajikan oleh suatu perusahaan adalah bauran pemasaran (marketing mix).

Keputusan pembelian sangat dipengaruhi oleh bauran pemasaran dari perusahaan. Setiap konsumen memiliki penilaian tersendiri dalam memutuskan sebuah produk yang akan mereka beli, mulai dari segi produk, harga, tempat dan promosi yang sesuai dengan kebutuhannya. Untuk dapat mengetahui tanggapan konsumen terhadap bauran pemasaran Ina Cookies, penulis melakukan wawancara awal terhadap 30 orang konsumen. Dari hasil wawancara tersebut dapat disimpulkan bahwa Ina Cookies sudah memiliki bauran pemasaran yang cukup baik, namun masih ada beberapa keluhan dari konsumen mengenai bauran pemasaran Ina 
Cookies, seperti pada tempat dimana penyabaran outlet masih belum menyebar terutama untuk wilayah Bandung Timur dan masih kurangnya promosi yang dilakukan oleh Ina Cookies. Hal ini mengindikasikan bahwa perlu adanya perbaikan dalam bauran pemasaran sehingga dapat meningkatkan keputusan pembelian konsumen.

Berdasarkan hasil wawancara dengan Bapak Djoko selaku Direktur Pemasaran PT. BCS, Ina Cookies merupakan perusahaan yang memiliki tingkat penjualan yang paling tinggi dibandingkan dengan J\&C Cookies dan La Diva Cookies. Hal ini diperkuat dengan data volume penjualan perusahaan dari tahun 2012 hingga tahun 2014 yang disajikan dalam tabel 1.2 berikut ini:

Tabel 1.2

Data Penjualan Ina Cookies, J\&C Cookies, dan La Diva Cookies

\begin{tabular}{|c|c|c|c|}
\hline \multirow{2}{*}{ Tahun } & \multicolumn{3}{|c|}{ Merek (Satuan Lusin) } \\
\cline { 2 - 4 } & Ina Cookies & J\&C Cookies & La Diva Cookies \\
\hline $\mathbf{2 0 1 2}$ & 13.889 & 15.340 & 1.165 \\
\hline $\mathbf{2 0 1 3}$ & 17.786 & 14.953 & 886 \\
\hline $\mathbf{2 0 1 4}$ & 19.682 & 14.365 & 208 \\
\hline
\end{tabular}

Sumber: Data internal PT. Bonli Cipta Sejahtera

Dari tabel tersebut dapat dilihat bahwa pada tahun 2012 penjualan Ina Cookies berada di bawah J\&C Cookies dan di atas La Diva Cookies. Pada tahun 2013 dan 2014 volume penjualan Ina Cookies meningkat dibandingkan dengan dua pesaingnya yang mengalami penurunan volume penjualan. Hal ini memberikan indikasi awal bahwa Ina Cookies memiliki strategi penjualan yang baik. Namun pada saat penulis melakukan wawancara awal, konsumen masih ada yang mengeluhkan beberapa permasalahan terkait dengan bauran pemasaran pada Ina Cookies.

\section{Rumusan Masalah}

1. Bagaimana bauran pemasaran yang dilakukan Ina Cookies?

2. Bagaimana keputusan pembelian konsumen dalam memilih kue kering Ina Cookies?

3. Seberapa besar pengaruh bauran pemasaran yang terdiri dari product, price, place dan promotion secara simultan terhadap keputusan pembelian produk Ina Cookies?

4. Seberapa besar pengaruh bauran pemasaran yang terdiri dari product, price, place dan promotion secara parsial terhadap keputusan pembelian produk Ina Cookies?

\section{Tujuan Penelitian}

Penelitian ini bertujuan untuk mengetahui dan menganalisis : 


\section{Fiera Aryati Natakusumah}

\section{Ai Lili Yuliati}

1. Bauran pemasaran yang dilakukan oleh Ina Cookies.

2. Keputusan pembelian konsumen dalam memilih kue kering Ina Cookies.

3. Seberapa besar pengaruh bauran pemasaran yang terdiri dari product, price, place dan promotion secara simultan terhadap keputusan pembelian produk Ina Cookies.

4. Seberapa besar pengaruh bauran pemasaran yang terdiri dari product, price, place dan promotion secara parsial terhadap keputusan pembelian produk Ina Cookies.

\section{Tinjauan Pustaka}

\section{Bauran Pemasaran}

Bauran pemasaran (marketing mix) merupakan kumpulan alat pemasaran terkontrol yang dipadukan perusahaan untuk menghasilkan respon yang diinginkan di pasar sasaran (Kotler \& Armstrong 2010: 75). Variabelvariabel dalam bauran pemasaran dikelompokan menjadi empat, yaitu product (produk), price (harga), place (tempat) dan promotion (promosi).

\section{Produk}

Pengertian produk menurut Kotler \& Armstrong (2010:248), adalah semua hal yang dapat ditawarkan kepada pasar untuk menarik perhatian, akuisisi, penggunaan, atau konsumsi yang dapat memuaskan suatu keinginan atau kebutuhan.

\section{Harga}

Pengertian harga menurut Kotler dan Armstrong (2010:76), adalah jumlah uang yang harus dibayarkan pelanggan untuk memperoleh produk.

\section{Tempat}

Menurut Kotler dan Armstrong (2010:76), tempat meliputi kegiatan perusahaan yang membuat produk tersedia bagi pelanggan sasaran.

\section{Promosi}

Menurut Kotler dan Armstrong (2010:76), promosi adalah aktivitas yang menyampaikan manfaat produk dan membujuk pelanggan untuk membelinya.

\section{Keputusan Pembelian}

Keputusan pembelian menurut Kotler \& Keller (2012: 188) adalah tahap dimana konsumen membentuk niat untuk membeli produk yang paling disukai, keputusan konsumen untuk memodifikasi, menunda, atau menghindar sangat dipengaruhi oleh resioko yang dirasakan. Tahap keputusan pembelian yang dilakukan konsumen terdiri Pemilihan produk, Pemilihan merek, Pemilihan saluran pemasaran, Waktu pembelian dan cara pembayaran.

\section{Penelitian Terdahulu}


Beberapa peneliti baik dari Indonesia maupun Luar Negeri telah melakukan penelitian mengenai pengaruh bauran pemasaran yang terdiri dari produk, harga, promosi dan tempat terhadap keputusan pembelian, yang menunjukkan bahwa terdapat pengaruh yang positif dan signifikan Bauran Pemasaran terhadap Keputusan Pembelian.Dari Indonesia diantaranya adalah: Suryadi Syam (2012), Abdul Hgalim (2013), Latoyah Damba (2013), Radinal Ekawanda (2014), Vina Soraya (2012), Saiz Wantini et al. (2013), Simbolon dan Marhayanie (2013), Erna Tiningrum (2014), Mega Christine Wangko (2013), Dara Patria Harjasiswi (2014).Dari Luar Negeri adalah: Bungdit Pungnirund (2013), Mucai et al. (2013), Pour et al. (2013), Rezky Purna Satit et al. (2012), B.K Suthat et al. (2014)

\section{Kerangka Pemikiran}

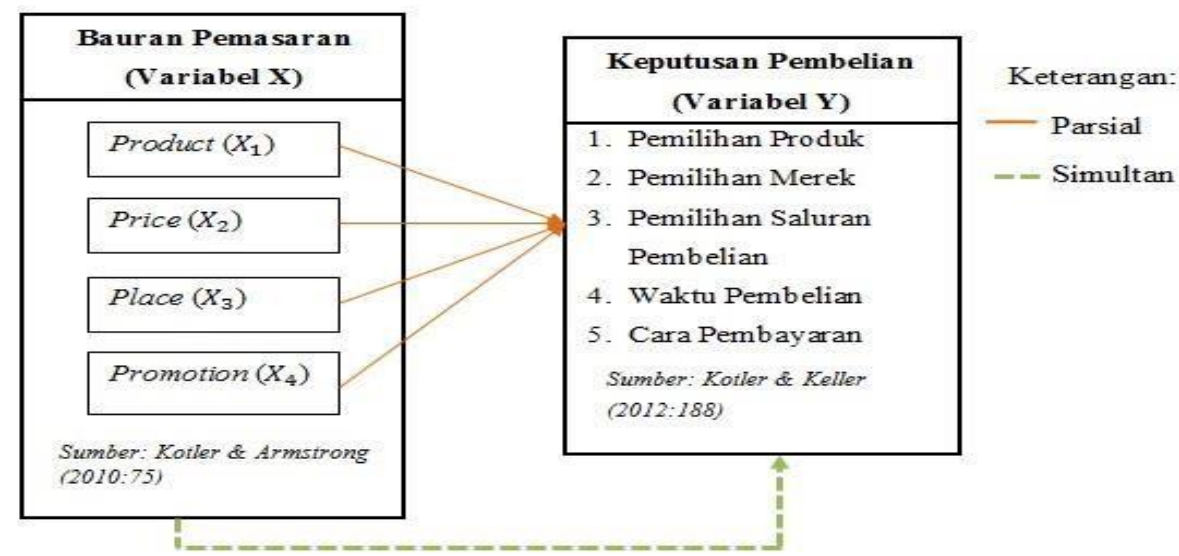

Gambar 2.1

Kerangka Pemikiran

\section{Hipotesis Penelitian}

Hipotesis merupakan jawaban sementara terhadap rumusan masalah penelitian, dimana masalah penelitian telah dinyatakan dalam bentuk kalimat pertanyaan. Berdasarkan kerangka pemikiran yang telah diuraikan di atas, hipotesis yang diajukan dan akan dibuktikan kebenarannya adalah "Terdapat pengaruh Bauran Pemasaran yang terdiri dari product, price, place dan promotion terhadap Keputusan Pembelian baik secara simultan maupun parsial" Metode Penellitian.

Metode yang digunakan dalam penelitian ini adalah metode kuantitatif dengan jenis penelitian deskriptif dan kausal. Sumber data menggunakan data primer dan skunder, teknik sampling menggunakan Non Probability sampling dengan insidental sampling. Teknik analisis data menggunakan analisis deskriptif dan analisis regresi linier berganda.Populasi dalam penelitian ini adalah konsumen yang pernah membeli kue kering Ina Cookies. Pada penelitian 


\section{Fiera Aryati Natakusumah}

\section{Ai Lili Yuliati}

ini, mengingat jumlah populasi tidak diketahui maka dalam menentukan jumlah sampel menggunakan rumus Bernoulli (Siregar, 2013: 37) sebagai berikut:

$$
\mathrm{n}=\frac{z^{2} p q}{e^{2}}
$$

Keterangan:

$\mathrm{n} \quad=$ jumlah sampel

$Z^{2} \quad=$ nilai $Z$ dari tingkat kepercayaan yang dibutuhkan

$\mathrm{P}=$ proposi yang diestimasi suatu atribut dadalam populasi

$\mathrm{q} \quad=1-\mathrm{p}$

e $\quad=$ error tolerance maksimum

Dalam penelitian ini menggunakan error level (tingkat kesalahan) sebesar 5\%. Maka jumlah sampel yang diperoleh adalah:

$$
\begin{aligned}
& n=\frac{1,96^{2}(0,5)(0,5)}{0,05^{2}} \\
& n=384,16 \text { responden }
\end{aligned}
$$

Berdasarkan hasil hitung sampel, diperoleh angka 384 untuk jumlah sampel minimum, tetapi dibulatkan menjadi 400 responden untuk mengurangi kesalahan pengisian kuesioner.

\section{Hasil Penelitian}

\section{Hasil Analisis deskriptif}

Berdasarkan hasil analisis deskriptif menunjukkanbahwa bauran pemasaran Ina Cookies yang terdiri dari produk, harga, tempat, dan promosi berada dalam kategori baik dengan nilai presentase sebesar $73,85 \%$. Keputusan pembelian konsumen termasuk dalam kategori baik dengan nilai presentase sebesar $78,71 \%$.

\section{Hasil Analisis Regresi Berganda}

Berdasarkan hasil pengolahan data dapat dirumuskan model persamaan regresi berganda sebagai berikut:

$\mathrm{Y}=\mathrm{a}+\mathrm{b}_{1} \mathrm{X}_{1}+\mathrm{b}_{2} \mathrm{X}_{2}+\mathrm{b}_{3} \mathrm{X}_{3}+\mathrm{b}_{4} \mathrm{X}_{4}$

$Y=0,695+0,441 X_{1}+0,110 X_{2}+0,147 X_{3}+0,155 X_{4}$

Berdasarkan persamaan tersebut dapat diuraikan sebagai berikut:

1. Konstanta $(a)=0,695$, artinya apabila variabel produk, harga, tempat, dan promosi bernilai nol maka keputusan pembelian bernilai 0,695 satuan.

2. Koefisien $X_{1}\left(b_{1}\right)=0,411$. Ini menunjukkan bahwa variabel produk berpengaruh secara positif terhadap keputusan pembelian pada kue kering Ina Cookies. Jika variabel produk 
ditingkatkan sebesar satu satuan dan variabel lainnya konstan, maka keputusan pembelian akan bertambah sebesar 0,411

3. Koefisien $\mathrm{X}_{2}\left(\mathrm{~b}_{2}\right)=0,110$. Ini menunjukkan bahwa variabel harga berpengaruh secara positif terhadap keputusan pembelian pada kue kering Ina Cookies. Jika variabel harga ditingkatkan sebesarsatu satuan dan variabel lainnyakonstan, maka keputusan pembelian akan bertambah sebesar 0,110.

4. Koefisien $X_{3}\left(b_{3}\right)=0,147$. Ini menunjukkan bahwa variabel tempat berpengaruh secara positif terhadap keputusan pembelian pada kue kering Ina Cookies. Jika variabel tempat ditingkatkan sebesar satu satuan dan variabellainnya konstan, maka keputusan pembelian akan bertambah sebesar 0,147.

5. Koefisien $X_{5}\left(b_{5}\right)=0,155$. Ini menunjukkan bahwa variabel promosi berpengaruh secara positif terhadapkeputusan pembelian pada kue kering Ina Cookies. Jika variabel promosi dtingkatkan sebesar satu satuan danvariabel lainnya konstan, maka keputusan pembelian akan bertambah sebesar 0,155.

\section{Uji Signifikansi Simultan (Uji-F)}

Kegunaan dari Uji $\mathrm{F}$ ini adalah untuk menguji apakah variabel bauran pemasaran ( $\mathrm{X}$ ) yang terdiri dari produk $\left(\mathrm{X}_{1}\right)$, harga $\left(\mathrm{X}_{2}\right)$, tempat $\left(\mathrm{X}_{2}\right)$, dan promosi $\left(\mathrm{X}_{4}\right)$, secara bersama-sama berpengaruh terhadap keputusan pembelian (Y).

\section{Tabel 4.1}

Hasil Uji Simultan

ANOVA

\begin{tabular}{|c|c|c|c|c|c|c|}
\hline \multicolumn{2}{|c|}{ Model } & \multirow{2}{*}{$\begin{array}{r}\text { Sum of Squares } \\
81,068\end{array}$} & df & Mean Square & $\mathrm{F}$ & Sig. \\
\hline \multirow{3}{*}{1} & Regression & & 4 & 20,267 & 103,590 &, $000^{\circ}$ \\
\hline & Residual & 77,280 & 395 & , 196 & & \\
\hline & Total & 158,347 & 399 & & & \\
\hline
\end{tabular}
a. Dependent Variable: KeputusanPembelian
b. Predictors: (Constant), Promosi, Harga, Tempat, Produk

Pada tabel 4.1 dapat dilihat Fhitung adalah 103,590 dengan tingkat signifikansi 0,000. Oleh karena itu, pada keduaperhitungan Fhitung $>$ Ftabel $(103,590>2,38)$ dan tingkat signifikansinnya $0,000<0,05$. Hal ini menunjukkan bahwaHol ditolak dan $\mathrm{H}_{02}$ diterima, yang artinya variabel bebas bauran pemasaran yang terdiri dari $\operatorname{produk}\left(X_{1}\right)$, harga $\left(X_{2}\right)$, tempat $\left(X_{3}\right)$, dan 


\section{Fiera Aryati Natakusumah}

\section{Ai Lili Yuliati}

promosi $\left(\mathrm{X}_{4}\right)$ secara bersama-sama berpengaruh secara signifikan terhadap keputusanpembelian (Y).

\section{Uji Signifikansi Parsial (Uji-T)}

Pengujian ini digunakan untuk menguji besarnya pengaruh varibel bebas secara parsial terhadap variabel terikat. Kegunaan dari Uji t ini adalah untuk menguji apakah variabel bauran pemasaran (X) yang terdiri dari produk, harga, tempat, dan promosi, secara parsial berpengaruh terhadap keputusan pembelian konsumen (Y).

Kriteria penilaian uji hipotesis secara parsial adalah:

1. thitung >ttabel dan nilai signifikansi kurang dari 0,05, maka ditolak dan diterima. Hal ini menunjukkan ada pengaruh yang signifikan dari variabel bebas terhadap variabel terikat.

2. thitung<ttabel dan nilai signifikansi lebih dari 0,05, maka diterima dan ditolak. Hal ini menunjukan tidak adanya pengaruh yang signifikan dari variabel bebas terhadap variabel terikat.

Tabel 4.2

Hasil Uji Parsial

\begin{tabular}{|c|c|c|c|c|c|c|}
\hline \multirow{2}{*}{\multicolumn{2}{|c|}{ Model }} & \multicolumn{2}{|c|}{ Unstandardized Coefficients } & \multirow{2}{*}{$\begin{array}{c}\text { Standardized } \\
\text { Coefficients } \\
\text { Beta }\end{array}$} & \multirow[t]{2}{*}{$t$} & \multirow[t]{2}{*}{ Sig. } \\
\hline & & B & Std. Error & & & \\
\hline \multirow{5}{*}{1} & (Constant) &, 695 & 157 & & 4,431 &, 000 \\
\hline & Produk &, 411 &, 047 & 419 & 8,680 &, 000 \\
\hline & Harga &, 110 &, 039 &, 130 & 2,812 &, 005 \\
\hline & Tempat &, 147 &, 041 &, 161 & 3,587 &, 000 \\
\hline & Promosi & , 155 &, 050 &, 149 & 3,113 &, 002 \\
\hline
\end{tabular}

Berdasarkan tabel 4.2 di atas dapat dilihat bahwa:

1. Dari hasil pengujian diperoleh nilai $\dagger$ untuk variabel produk menunjukkan nilai $t=8,680$ dengan nilai signifikansi sebesar 0,000 . Dengan thitung $(8,680)$ tidak berada dintara $-1,966$ dan 1,966 dan tingkat signifikansi $0,000<0,05$, maka ditolak dan diterima, artinya secara parsial produk berpengaruh secara positif dan signifikan terhadap keputusan pembelian kue kering Ina Cookies.

2. Dari hasil pengujian diperoleh nilai $\dagger$ untuk variabel harga menunjukkan nilai $t=2,812$ dengan nilai signifikansi sebesar 0,000 . Dengan thitung $(2,812)$ tidak berada antara $-1,966$ 
dan 1,966 dan tingkat signifikansi 0,005 < 0,05, maka ditolak dan diterima, artinya secara parsial harga berpengaruh secara positif dan signifikan terhadap keputusan pembelian kue kering Ina Cookies.

3. Dari hasil pengujian diperoleh nilai $\dagger$ untuk variabel tempat menunjukkan nilai $t=3,587$ dengan nilai signifikansi sebesar 0,000. Dengan thitung $(3,587)$ tidak berada dintara $-1,966$ dan 1,966 dan tingkat signifikansi $0,000<0,05$, maka ditolak dan diterima, artinya secara parsial tempat berpengaruh secara positif dan signifikan terhadap keputusan pembelian kue kering Ina Cookies.

4. Dari hasil pengujian diperoleh nilai $t$ untuk variabel promosi menunjukkan nilai $t=3,113$ dengan nilai signifikansi sebesar 0,002. Dengan thitung $(3,113)$ tidak berada dintara $-1,966$ dan 1,966 dan tingkat signifikansi 0,002 < 0,05, maka ditolak dan diterima, artinya secara parsial promosi berpengaruh secara positif dan signifikan terhadap keputusan pembelian kue kering Ina Cookies.

\section{Hasil Uji Koefisien Determinan $\left(\mathbf{R}^{2}\right)$}

Koefisien determinasi $\left(R^{2}\right)$ digunakan untuk mengetahui seberapa besar kontribusi variabel bebas (X) yaitu produk, harga, tempat dan promosi terhadap variabel terikat (Y) yaitu keputusan pembelian konsumen. Rumus koefisien determinasi adalah $\mathrm{Kd}=\mathrm{r}^{2} \times 100 \%$. Berdasarkan hasil tabel diatas diketahui nilai $r^{2}$ adalah 0,512. Maka perhitungan koefisien determinasi adalah sebagai berikut :

$$
\begin{aligned}
\mathrm{Kd} & =0,512 \times 100 \% \\
& =51,2 \%
\end{aligned}
$$

Berdasarkan perhitungan, koefisien determinasi nilai perolehannya sebesar 51,2\%. Dari nilai tersebut dapat diartikan bahwa besarnya pengaruh bauran pemasaran terhadap Keputusan Pembelian adalah $51,2 \%$, sedangkan sisanya sebesar $48,8 \%$ dipengaruhi oleh variabel lain yang tidak diteliti dalam penelitian ini.

\section{Pembahasan Hasil Penelian}

Berdasarkan hasil analisis deskriptif, secara keseluruhan variabel bauran pemasaran berada dalam kategori baik dengan skor total adalah 25.111 atau sebesar $73,855 \%$. Hal ini menunjukkan bawa Ina Cookies telah menciptakan bauran pemasaran yang sudah sesuai dengan keinginan dan kebutuhan konsumen, seperti Ina Cookies mampu menciptakan kue kering berkualitas baik (dari segi rasa, aroma, terkstur, dan warna), harga kue kering yang 


\section{Fiera Aryati Natakusumah}

Ai Lili Yuliati

ditawarkan Ina Cookies sebanding dengan kualitas yang didapatkan, Ina Cookies memiliki outlet penjualan resmi sehingga memudahkan konsumen untuk mendapatkan produk, dan promosi penjualan yang dilakukan menarik perhatian konsumen untuk membeli kue kering Ina Cookies.

Keputusan pembelian konsumen dalam memilih kue kering Ina Cookies secara keseluruhan termasuk dalam kategori baik dengan nilai total 8.871 atau $78,71 \%$. Hal ini menunjukkan bahwa konsumen memutuskan untuk memilih Ina Cookies karena kue kering Ina Cookies berkualitas dan terpercaya (dari segi rasa, aroma, tekstur, dan warna), konsumen memilih kue kering Ina Cookies karena adanya outlet penjualan resmi, konsumen membeli kue kering Ina Cookies karena adanya hari besar, dan konsumen memilih Ina Cookies karena adanya kemudahan dalam melakukan transaksi pembayaran.

Bauran pemasaran yang terdiri dari produk,harga, tempat, dan promosi secara simultan berpengaruh positif dan signifikan terhadap keputusan pembelian konsumen dalam memilih kue kering Ina Cookies. Produk, harga, tempat, dan promosi secara parsial berpengaruh positif dan signifikan terhadap keputusan pembelian.

\section{Kesimpulan dan Saran}

\section{Kesimpulan}

Berdasarkan hasil penelitian yang telah dilakukan mengenai pengaruh bauran pemasaran terhadap keputusan pembelian pada kue kering Ina Cookies, dapat diambil beberapa kesimpulan yang diharapkan dapat memberikan jawaban terhadap permasalahan yang dirumuskan dalam penelitian ini adalah sebagai berikut:

\section{Bauran pemasaran yang dilakukan Ina Cookies}

Bauran pemasaran pada Ina Cookies dimata responden secara keseluruhan berada dalam kategori baik. Hal ini menunjukkan bahwa Ina Cookies telah menciptakan bauran pemasaran yang dapat memenuhi keinginan dan kebutuhan konsumen seperti membuat kue kering berkualitas serta memperbanyak jenis-jenis kue, menawarkan harga yang sesuai dengan kualitas produk, memiliki outlet penjualan di kota Bandung, dan membuat promosi yang dapat menarik perhatian konsumen untuk membeli kue kering Ina Cookies.

\section{Keputusan pembelian konsumen dalam memilih kue kering Ina Cookies}

Keputusan pembelian konsumen secara keseluruhan masuk dalam kategori baik. Hal ini menunjukkan bahwa konsumen memutuskan untuk memilih kue kering Ina Cookies karena kue kering Ina Cookies berkualitas (dari segi rasa, aroma, tekstur, dan warna), konsumen percaya 
terhadap kualitas kue kering merek Ina Cookies, konsumen memilih kue kering Ina Cookies karena adanya outlet penjualan resmi, konsumen membeli kue kering Ina Cookies karena adanya hari besar, dan konsumen memilih Ina Cookie karena adanya kemudahan dalam melakukan transaksi pembayaran.

Pengaruh bauran pemasaran yang terdiri dari product, price, place, dan promotion secara simultan terhadap keputusan pembelian kue kering Ina Cookies.

Bauran pemasaran yang terdiri dari produk, harga, tempat, dan promosi secara simultan berpengaruh positif dan signifikan terhadap keputusan pembelian konsumen dalam memilih kue kering Ina Cookies. Hal ini menunjukkan apabila keempat variabel ini secara bersamasama diterapkan dapat mempengaruhi keputusan pembelian konsumen.

\section{Pengaruh bauran pemasaran yang terdiri dari product, price, place, dan promotion secara parsial terhadap keputusan pembelian kue kering Ina Cookies.}

Berdasarkan uji t bauran pemasaran yang terdiri dari sub variabel produk, harga, tempat, dan promosi secara parsial berpengaruh secara positif dan signifikan terhadap keputusan pembelian kue kering Ina Cookies dimana produk merupakan variabel yang memiliki pengaruh paling besar. Penelitian ini mendukung penelitian sebelumnya yang dilakukan oleh Suryadi Syam (2012) yang menyatakan bahwa variabel produk memberikan pengaruh paling besar terhadap keputusan pembelian.

\section{Saran}

\section{Saran Bagi Perusahaan}

Berdasarkan hasil kesimpulan yang telah diuraikan di atas, peneliti dapat memberikan saran yang kiranya dapat bermanfaat bagi pihak Ina Cookies yaitu:

1. Ina Cookies agar mempertahankan atau meningkatkan strategi bauran pemasaran yang sudah dinyatakan baik menurut tanggapan responden, sehingga kedepannya bauran pemasaran Ina Cookies bisa berada dalam kategori sangat baik. Peningkatan tersebut bisa dilakukan dengan cara menggunakan bahan baku kue kering yang lebih baik sehingga dapat menghasilkan kue kering yang memiliki rasa, aroma, tekstur, dan warna berkualitas baik, memvariasikan harga kue kering berdasarkan segmen misalnya menawarkan kue kering untuk segmen menengah kebawah atau berdasarkan waktu misalnya membedakan harga kue kering pada saat hari biasa dan pada saat hari besar seperti lebaran atau natal, dan memperluas lagi outlet penjualan agar semakin tersebar di wilayah Bandung. 


\section{Fiera Aryati Natakusumah}

Ai Lili Yuliati

2. Berdasarkan hasil penelitian, indikator keputusan pembelian yang mendapatkan nilai terendah namun masuk dalam kategori baik adalah kualitas produk. Disarankan agar perusahaan bisa lebih meningkatkan lagi kualitas kue kering. Misalnya dengan meningkatkan kualitas bahan baku agar kue kering yang dihasilkan memiliki rasa yang enak, aroma yang baik, tekstur kue yang tidak mudah hancur, dan warna yang baik.

3. Ina Cookies agar memperhatikan faktor-faktor lain yang berpengaruh terhadap keputusan pembelian misalnya celebrity endorse, sehingga akan meningkatkan keputusan pembelian konsumen dalam memilih kue kering Ina Cookies.

4. Perusahaan agar lebih memperhatikan variabel produk yang memiliki pengaruh paling besar terhadap keputusan pembelian, dengan cara terus meningkatkan kualitas produk (dari segi rasa, aroma, tektur, dan warna) dan terus melakukan inovasi dengan menciptakan jenis dan rasa kue kering yang baru sehingga dapat menarik perhatian konsumen untuk membelinya.

\section{DAFTAR PUSTAKA}

Kotler, Philip \& Gary Armstrong. (2010). Principles of Marketing. edisi 13. United States of America: Pearson.

Kotler, Philip., \& Keller, Kevin Lane. (2012). Marketing Management 14th edition. Harlow: PearsonEducation.

Siregar, Syofian. (2013). Statistik Parametrik untuk Penelitian Kuantitatif. Jakarta: Bumi Aksara.

Simbolon, Yulia Kristina \& Marhayanie. Pengaruh Strategi Bauran Pemasaran Terhadap Keputusan Pembelian Kartu Simpati Ttelkomsel Pada Mahasiswa Fakultas Ekonomi Program S1 Universitas Sumatra Utara. Jurnal Pendidikan Bisnis \& Ekonomi Vol.1 No.2, Hal $1-12$.

Syam, Suryadi. (2012). Pengaruh Bauran Pemasaran Terhadap Keputusan Pembelian Motor Yamaha Pada PT. Suraco Jaya Abadi Motor Di Makassar. Fakultas Ekonomi dan Bisnis Universitas Hasanuddin.

www.antaranews.com, diakses 20 Febuari 2015

www.budpar.go.id/userfiles/file/perkembanganrestoranperprov2007-2010.pdf (diakses 16 Juni 2015) 


\section{KUESIONER}

\section{Screening Question}

Apakah anda pernah membeli kue kering Ina Cookies?
a. $\mathrm{Ya}$
b. Tidak (Jika tidak, anda tidak perlu melanjutkan mengisi kuesioner ini, terimakasih)

\section{Bagian 1. Identitas responden}

1. Usia anda pada saat ini adalah:
a. $26-35$ tahun
b. $36-45$ tahun
c. $>45$ tahun

2. Pekerjaan anda adalah:
a. Pegawai Negeri/ Swasta
b. Wiraswasta
c. Lainnya (Sebutkan)....

3. Pendapatan perbulan anda adalah:
a. Rp. $2.000 .000-\operatorname{Rp} 4.000 .000$
b. Rp. $4.000 .001-\operatorname{Rp} 6.000 .000$
c. $>\operatorname{Rp} 6.000 .001$

4. Berapa kali anda melakukan pembelian kue kering Ina Cookies pertahun? a. 1 kali - 2 kali

b. 3 kali - 4 kali

c. $>5$ kali

\section{Bagian II.}

\section{Petunjuk Pengisian}

1. Pilihlah salah satu jawaban yang menurut anda sesuai dengan pilihan anda di setiap pertanyaan yang diberikan. Berilah tanda $(\sqrt{ })$ pada kolom yang tersedia.

2. Sekali lagi anda dapat mengisi kuisioner ini apabila anda pernah membeli kue kering Ina Cookies. 


\section{Fiera Aryati Natakusumah}

Ai Lili Yuliati

3. Jawaban terdiri atas lima pilihan, antara lain:
a. Sangat Setuju
(SS)
b. Setuju
c. Cukup Setuju
d. Tidak Setuju
e. Sangat Tidak Setuju

\section{Bagian III. Kuesioner}

\begin{tabular}{|c|c|c|c|c|c|c|}
\hline \multirow{2}{*}{ No } & \multirow{2}{*}{ Pernyataan } & & \multicolumn{3}{|c|}{ Jawaban } & \multirow[b]{2}{*}{ STS } \\
\hline & & SS & ST & CS & TS & \\
\hline \multirow[t]{2}{*}{ I } & Bauran Pemasaran & & & & & \\
\hline & Produk (Product) $\left(X_{1}\right)$ & & & & & \\
\hline 1. & $\begin{array}{l}\text { Kue kering Ina Cookies memiliki kualitas } \\
\text { yang baik (dari segi rasa, aroma, tekstur, } \\
\text { dan warna) }\end{array}$ & & & & & \\
\hline 2. & $\begin{array}{l}\text { Ina Cookies merupakan merek kue } \\
\text { kering yang memiliki kualitas yang } \\
\text { terpercaya (dari segi rasa, aroma, } \\
\text { tekstur, dan warna) }\end{array}$ & & & & & \\
\hline 3. & $\begin{array}{l}\text { Kue kering yang dijual Ina Cookies } \\
\text { dalam kondisi yang baik (dari segi rasa, } \\
\text { aroma, tekstur, dan warna) }\end{array}$ & & & & & \\
\hline 4. & $\begin{array}{l}\text { Ina Cookies memiliki berbagai jenis kue } \\
\text { kering }\end{array}$ & & & & & \\
\hline 5. & $\begin{array}{l}\text { Kemasan kue kering Ina Cookies } \\
\text { menarik }\end{array}$ & & & & & \\
\hline 6. & $\begin{array}{l}\text { Harga kue kering yang ditawarkan Ina } \\
\text { Cookies terjangkau oleh pendapatan } \\
\text { saya }\end{array}$ & & & & & \\
\hline 7. & $\begin{array}{l}\text { Saya dapat menemukan daftar harga } \\
\text { kue kering Ina Cookies dengan mudah }\end{array}$ & & & & & \\
\hline
\end{tabular}




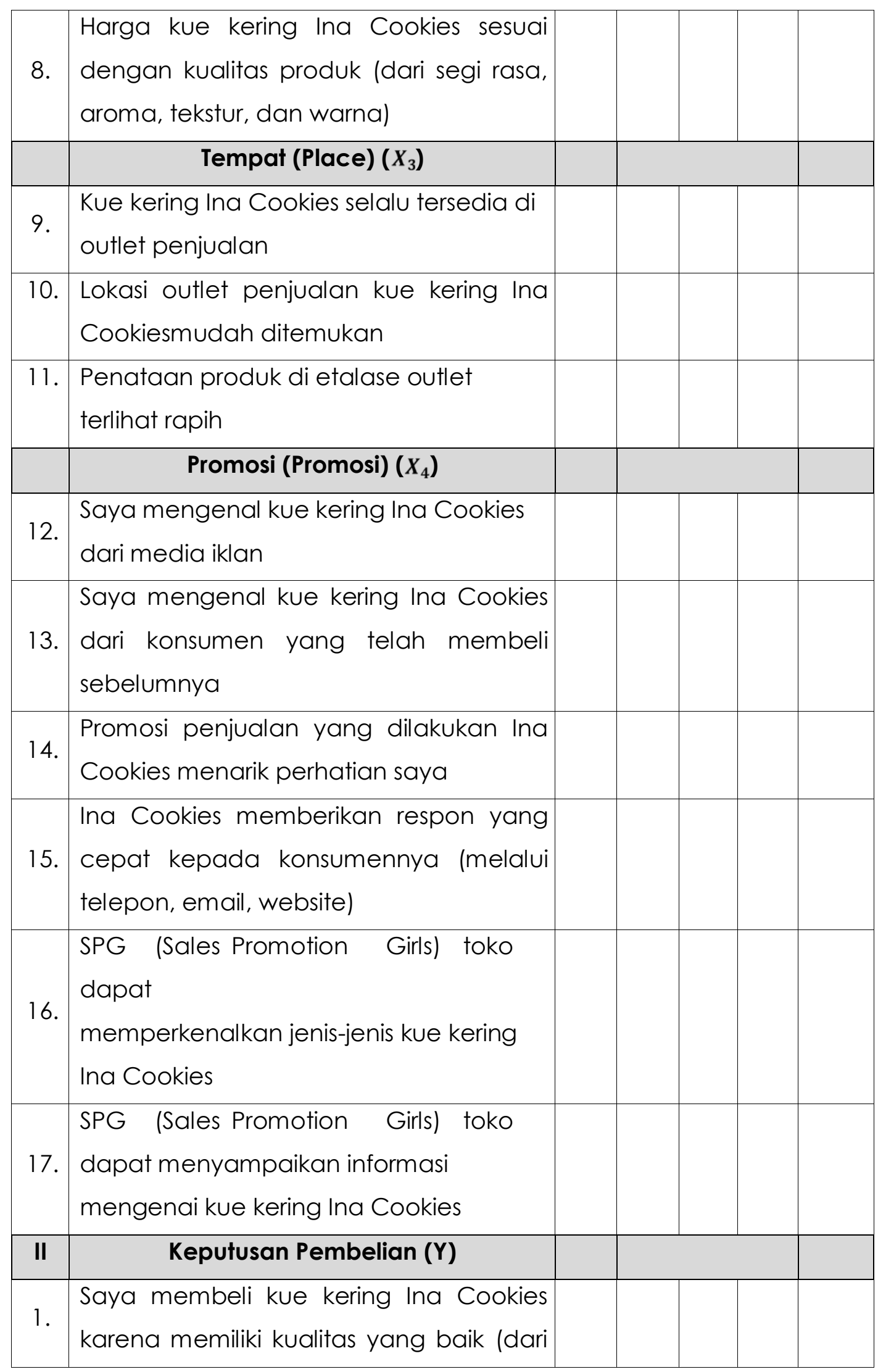


Fiera Aryati Natakusumah

Ai Lili Yuliati

\begin{tabular}{|l|l|l|l|l|l|}
\hline segi rasa, aroma, tekstur, dan warna) & & & & & \\
\hline 2. $\begin{array}{l}\text { Saya membeli kue kering Ina Cookies } \\
\text { karena saya percaya terhadap kualitas } \\
\text { kue kering Ina Cookies } \\
\text { (kualitas dari segi rasa, aroma, tekstur, } \\
\text { dan warna) }\end{array}$ & $\begin{array}{l}\text { Saya membeli kue kering Ina Cookies } \\
\text { pada outlet resmi karena lebih terjamin } \\
\text { keasliannya }\end{array}$ \\
4. $\begin{array}{l}\text { Saya membeli kue kering Ina Cookies } \\
\text { saat hari besar seperti lebaran atau } \\
\text { natal } \\
\text { Saya membeli kue kering Ina Cookies } \\
\text { karena adanya kemudahan dalam } \\
\text { melakukan pembayaran (seperti } \\
\text { pembayaran dapat dilakukan dengan } \\
\text { tunai, debit, dan kredit) }\end{array}$
\end{tabular} \mid \begin{tabular}{l} 
\\
\hline
\end{tabular}

